\title{
Analysis of the Impact of the Existence of Tano Tubu Office on the Emergence of a New Community Business Sector
}

\author{
Dirman Sihombing ${ }^{1}$, Sirojuzilam ${ }^{2}$, Badaruddin $^{3}$ \\ ${ }^{1,2,3}$ Universitas Sumatera Utara, Indonesia
}

\begin{abstract}
The aims of this study is to analysis the impact of existence of Tano Tubu Office on the Emergence of a New Community Business Sector. This study uses a descriptive method with a quantitative approach. The result shows that there is a difference between the average income of business people around the Tano Tubu Office in the period before the Tano Tubu office and after the Tano Tubu office. The average income in the period before the establishment of the Tano Tubu Office was Rp. 2,163,382.93, - , while the average value of income in the period after the establishment of Tano Tubu Office was Rp. 4,183,333.33 ,. The existence of Tano Tubu Offices has a positive impact on increasing the income of the business community around it. This is indicated by the higher average income in the period after the establishment of Tano Tubu Office compared to the average income in the period before the establishment of Tano Tubu Office.
\end{abstract}

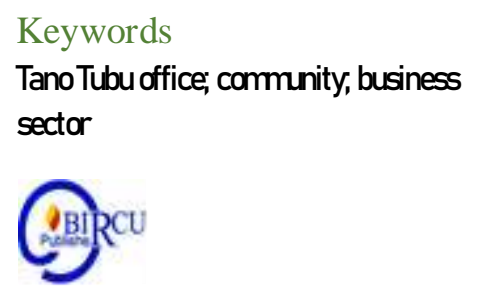

\section{Introduction}

Humbang Hasundutan Regency is a district resulting from the division of North Tapanuli Regency in 2003. The regional expansion is expected to be able to shorten the span of government control, so that community services and development can be faster and more effective. According to Siswanto (2009), in relation to regional expansion, philosophically, the purpose of regional expansion has two interests, namely the approach to public service delivery to the community, and to improve the welfare of local communities.

According to Sirojuzilam (2017), the effort to expand the region is a breakthrough in an effort to accelerate regional growth and equal distribution of development results. It should be realized that this effort is not enough because a decentralization euphoria requires an integrated, coordinating and comprehensive system. For this reason, several important things that need attention in terms of regional expansion are community empowerment, spatial planning, cross-border spatial relationships (cooperation between regions, creating new growth centers by taking into account the effects of the influence of boundary areas), and joint budgets (budget cooperation ).

Development is a systematic and continuous effort made to realize something that is aspired. Development is a change towards improvement. Changes towards improvement require the mobilization of all human resources and reason to realize what is aspired. In addition, development is also very dependent on the availability of natural resource wealth. The availability of natural resources is one of the keys to economic growth in an area. (Shah et al, 2020)

Development in accordance with government targets and targets is expected to be able to sustain economic growth. The existence of public deposits will be able to increase economic growth. This is in line with Suhel's (2015) opinion that public savings in the form 
of savings, time deposits and current accounts if used for various economic activities will function the same as investments which cause an increase in the region's output so that it will increase the region's income and create economic growth. (Pradata et al, 2020)

According to Sirojuzilam (2017), regional community development is a planned program that focuses on community needs, requires technical assistance from experts from various fields, and prioritizes joint activities to foster active community participation in development. Building territory is developing people with all their rights and obligations that need attention. Regional development needs to be guided by a clear vision and mission, because development is to achieve certain goals.

The construction of office buildings must be in accordance with their respective functions. This is intended to support government activities in serving the community. Office development is in line with the construction of other facilities, such as road networks as access to offices, electricity networks to support activities using electronic devices and other public facilities such as ATMs. The construction of offices and some of its supporting facilities will certainly provide added value to the function and aesthetics of an area.

At the time of the establishment of Humbang Hasundutan Regency, the office buildings used were buildings that existed when Doloksanggul District was still under the administration of North Tapanuli Regency. The existing office facilities are facilities for the sub-district level. This facility is very minimal to support district level government affairs. For this reason, offices were built which are spread across several office areas.

The government office complex of Humbang Hasundutan Regency was built in Doloksanggul which is the capital of Humbang Hasundutan Regency. The distribution of government offices built by the Humbang Hasundutan Regency Government is the Bukit Inspirasi Office Complex, the Tano Tubu Office Complex and the Purba Office Complex.

The Tano Tubu office complex was built in an area traversed by the national road from North Tapanuli Regency to Samosir and Dairi Regencies, to be precise in Tano Tubu, Doloksanggul District, Humbang Hasundutan Regency. As for the distribution of buildings in the Tano Tubu office complex, namely: Population and Civil Registration Service, Regional Asset Income Management Agency, Health Service, Social Service, Housing and Settlement Service, Communication and Information Service, Animal Husbandry Service, Education Office, DPRD Secretariat, Planting Service One Stop Integrated Licensing Capital.

\section{Review of Literatures}

\subsection{Government Office Areas}

The government area is a place to carry out all matters relating to government, be it political and administrative activities, as well as all activities related to matters concerning politics and government. One of the goals of planning the area is to improve the quality of services for the community where it cannot be separated from the role of the government itself in implementing it (Purba, 2005 in Damanik, 2014).

Understanding government and governance can be found in a variety of literature that discusses political issues. The government is etymologically derived from the Greek word, "Kubernan" or ship captain. It means to look forward. The word command has four elements namely first, there are two related parties, second, both parties have a contractual relationship. (Halik et al, 2020)

Hartshorn (1980) in Kustiawan (2000) states that in relation to the location pattern, the stages of office development as well as production locations are as follows: 
1. Centralization, namely the concentration of all functions in one location,

2. Fragmentation, namely the transfer of several production functions from agglomeration activities to maximize environment advantages,

3. Dispersion, the occurrence of a shift in all production functions to the sub-city center,

4. Diffusion, the occurrence of displacement of several functions from the sub-city center to the hierarchical city center below where coordination is carried out by maximizing telecommunications facilities.

Furthermore, Kustiawan (2000) states that from various literature theoretically it can be identified that the factors that influence or determine office locations include: communication factors; accessibility; prestigious value; surrounding environment; labor; as well as tread appeal.

Government-built service centers such as schools, hospitals, health centers, post offices, banks, terminals, stations, markets and others by the Government to meet and serve the general public in meeting their needs. The development of service centers certainly has a purpose other than to meet the needs of the community at large, it is also expected to be able to support regional development, space utilization and even job creation (Pane et al. 2013).

The presence of new offices in an area will have a major impact on the number of workers which will then develop into a residence for a large number of workers. It is a logical consequence that the land that is not built will turn into residential places (Damanik, 2014).

\subsection{Income}

According to Maryatmo and Susilo (1996), income is the total amount of money received by a family or a person during a certain period, usually one year. Community income thus is the total amount of revenue received in a particular year, both from agricultural production and from industrial and trade production and other sectors.other.

Lexically, income is defined as the result of work or effort in the form of money or goods. One form of income is wages or salaries, which means money paid in return for services or as payment for labor that has been spent doing something (Ministry of Educationand Indonesian Culture, 1995).

The level of household income depends on the types of activities carried out. Activities that include capital or skills that have higher labor productivity will eventually be able toprovide greater income (Kasasyono, 1988).

The income of each person (personal distribution of income) is the indicator most often used by economists to calculate the amount of income received by each individual or household. There are two approaches to find out or measure a person's income, namely through the value of production and value of acceptance (Warpani, 1984).

According to Djojohadikusumo (1960), if income is viewed from the point of view of revenue, income includes: (a) wages, salaries; (b) house rent and land lease; (c) company profits; (d) interest received on loans, shares, bonds and so on.

\subsection{Small business}

Based on the Law of the Republic of Indonesia Number 20 of 2008 concerning Micro, Small, and Medium Enterprises, the definition of Small Business is a productive economic business that stands alone, which is carried out by individuals or business entities that are not a subsidiary or branch of a company that is owned, controlled, or become part of, either directly or indirectly, of a Medium or Large Business that meets the criteria for Small Business as follows: 
a) has net assets of more than Rp.50,000,000.00 (fifty million rupiah) up to a maximum of Rp. 500,000,000.00 (five hundred million rupiah) excluding land and buildings for business premises; or

b) has annual sales revenue of more than Rp. 300,000,000.00 (three hundred million rupiah) up to a maximum of Rp. 2,500,000,000.00 (two billion five hundred million rupiah)

\section{Reseach Methods}

\subsection{Types of Research}

This study uses a descriptive method with a quantitative approach.Quantitative descriptive research is a research method that aims to describe existing phenomena, which are taking place now or in the past (Sugiono, 2007). The data described isThe data obtained from the study population were then analyzed according to the statistical methods used.

\subsection{Research Sites}

The research was conducted in the area around the Tano Tubu office, Pasaribu Village, Doloksanggul District, Humbang Hasundutan Regency, North Sumatra Province. The reason for choosing this location is based on the author's observation that many people live and open businesses in the area around the Tano Tubu office after the establishment of the Tano Tubu office.

\subsection{Types and Sources of Data}

This study uses primary data and secondary data. Primary data is obtained directly from respondents and parties who are competent with the existing problems through questionnaires. Secondary data were obtained from various data / reports from agencies such as BPS Humbang Hasundutan, Regional Secretariat of Humbang Hasundutan Regency, Bappeda Humbang Hasundutan, PUPR Humbang Hasundutan Office, Humbang Hasundutan Regional Asset Income Financial Management Agency, Doloksanggul Sub-district Office and other related agencies.

\section{Discussion}

Government-built service centers such as schools, hospitals, health centers, post offices, banks, terminals, stations, markets and others by the Government to meet and serve the general public in meeting their needs. The development of service centers certainly has a purpose other than to meet the needs of the community at large, it is also expected to be able to support regional development, space utilization and even job creation (Pane et al. 2013).

The increase in population as a direct result of the urbanization process has become a new market opportunity for community economic activities in line with the increasing demand for necessities. In addition to this, the concentration of the population at one location will certainly have an impact on spatial patterns in the area (Lase, 2010).

The construction of an office complex in Tano Tubu led to a movement of the people towards the office complex, both civil servants, people who deal with the government and people who live around the office area. Population mobilization has resulted in an increase in demand for certain needs in office locations. This request opens business opportunities around offices.

Initial observations made by the author that a lot of land has been built around the Tano Tubu office. The constructed land includes the establishment of community settlements, shop houses / shophouses and kiosks where people open food and beverage stalls, stalls for daily 
necessities, photocopying and binding businesses, business selling office stationery (ATK), computer rental and printing / print. This phenomenon has resulted in a shift in land use around the Tano Tubu office building.

Tano Tubu Office was built in 2004. As for the small business actors who opened a business around the Tano Tubu Office were dominated by business actors who opened a business after the construction of the Tano Tubu Office. Meanwhile, small businesses that were already running before the Tano Tubu office were built were only $3.33 \%$ of the total respondents.

Table 1. Analysis of the frequency of characteristics of small businesses based on length of business

\begin{tabular}{clcc}
\hline No. & \multicolumn{1}{c}{ Length of Business } & Amount & Percentage \\
\hline 1. & 0-5 Years & 10 & $33.33 \%$ \\
2. & 6-10 years & 8 & $26.67 \%$ \\
3. & 11-15 years & 11 & $36.67 \%$ \\
4. & 16 years and over & 1 & $3.33 \%$ \\
\hline \multicolumn{2}{r}{ Total } & $\mathbf{3 0}$ & $\mathbf{1 0 0 \%}$ \\
\hline
\end{tabular}

Source: Primary data, processed, 2019

As many as $86.67 \%$ of respondents stated that their decision to determine the location of the business was influenced by the existence of the Tano Tubu Office, while $13.33 \%$ stated that the decision to determine the place of business was not influenced by the existence of the Tano Tubu Office.

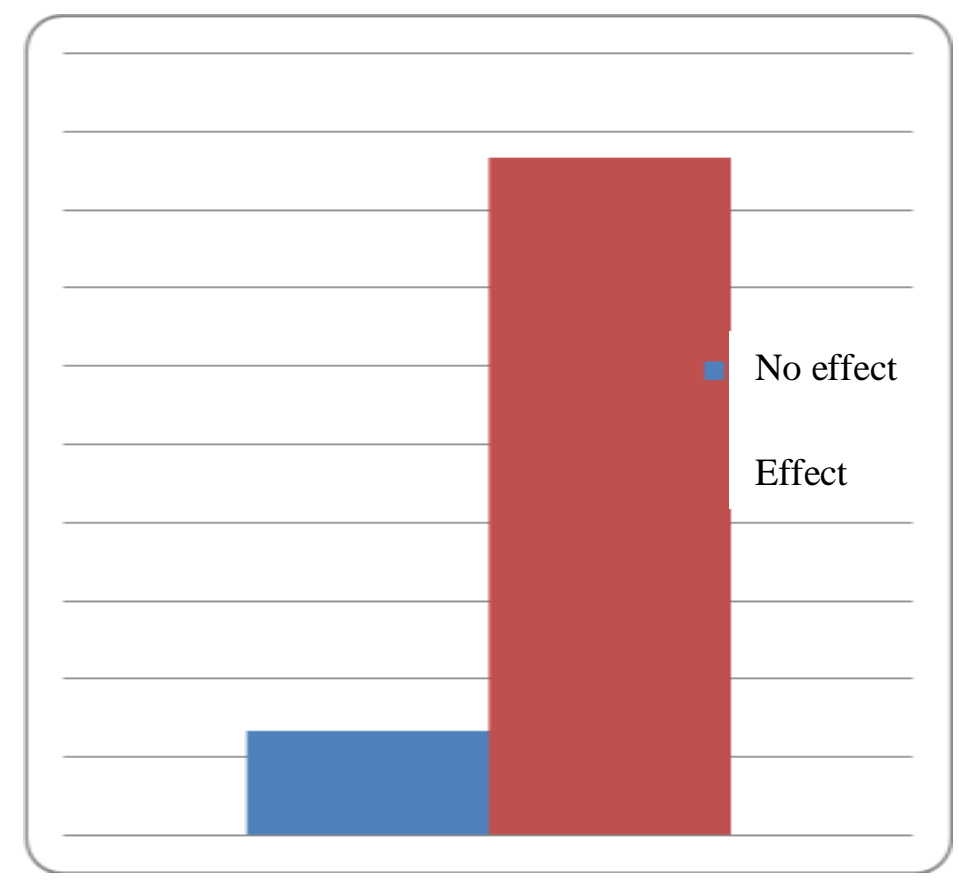

Source: Primary data, processed, 2019

Figure 1. Graph analysis of respondents' opinions about the influence of Tano Tubu Offices in determining business locations 
Table 2. Analysis of respondents' opinions about the influence of Tano Tubu Offices in determining business locations

\begin{tabular}{|c|c|c|c|c|c|}
\hline \multirow{3}{*}{ No. } & \multirow{3}{*}{ Type of business } & \multicolumn{4}{|c|}{$\begin{array}{l}\text { The Effect of Tano Tubu Offices on } \\
\text { Determination of Business Location }\end{array}$} \\
\hline & & \multicolumn{2}{|c|}{ No Effect } & \multicolumn{2}{|c|}{ Take Effect } \\
\hline & & Amount & Percentage & Amount & Percentage \\
\hline 1. & Food and beverage stalls & 3 & $23.08 \%$ & 10 & $76.92 \%$ \\
\hline 2. & Photocopy and binding services & 0 & $.0 \%$ & 1 & $100 \%$ \\
\hline 3. & Daily necessities stalls & 1 & $100 \%$ & 0 & $.0 \%$ \\
\hline 4. & $\begin{array}{l}\text { Food and beverage stalls }+ \\
\text { Photocopy and binding services }\end{array}$ & 0 & $.0 \%$ & 2 & $100 \%$ \\
\hline 5. & $\begin{array}{l}\text { Food and beverage stalls }+ \text { Sales } \\
\text { of office stationery }\end{array}$ & 0 & $.0 \%$ & 1 & $100 \%$ \\
\hline 6. & $\begin{array}{l}\text { Food and beverage stalls + daily } \\
\text { necessities stalls }\end{array}$ & 0 & $.0 \%$ & 5 & $100 \%$ \\
\hline 7. & $\begin{array}{l}\text { Photocopy and binding services } \\
+ \text { sales of office stationery }\end{array}$ & 0 & $.0 \%$ & 4 & $100 \%$ \\
\hline 8. & $\begin{array}{l}\text { Food and beverage stalls }+ \\
\text { Photocopy and binding services } \\
+ \text { Sales of office stationery }\end{array}$ & 0 & $.0 \%$ & 2 & $100 \%$ \\
\hline 9. & $\begin{array}{l}\text { Food and beverage stalls }+ \\
\text { Office stationery sales }+ \text { Stalls } \\
\text { for daily necessities }\end{array}$ & 0 & $.0 \%$ & 1 & $100 \%$ \\
\hline \multicolumn{2}{|c|}{ TOTAL } & 4 & $13.33 \%$ & 26 & $86.67 \%$ \\
\hline
\end{tabular}

Source: Primary data, processed, 2019

From the observations at the research location, it can be seen that several types of small businesses run by the community are food and beverage stalls, photocopy and binding services, sales of office stationery and stalls for daily necessities. As many as $90 \%$ of the total respondents stated that the decision to determine the type of business was influenced by the existence of the Tano Tubu Office, while 10\% of the respondents stated that the decision to determine the type of business was not influenced by the existence of the Tano Tubu Office.

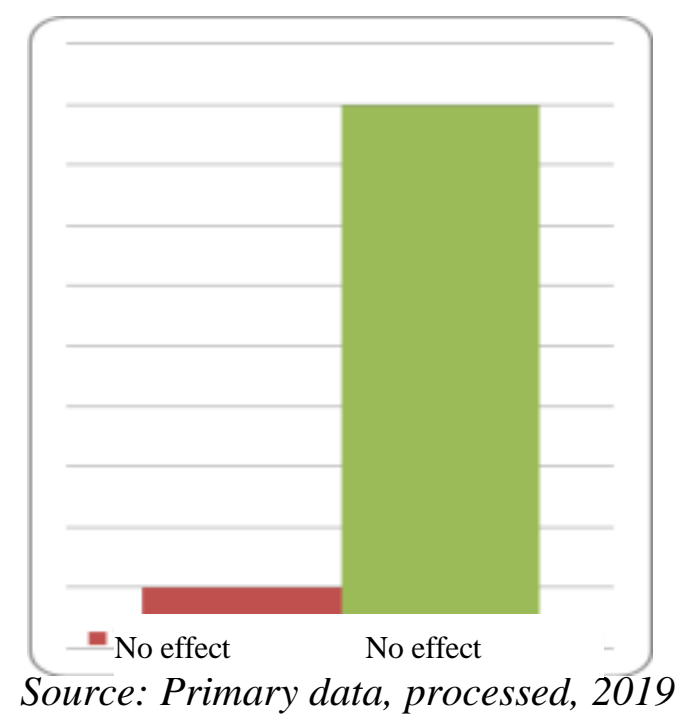

Figure 2. Graph analysis of respondents' opinions about the influence of Tano Tubu Offices in determining the type of business 
The determination of the type of business that is influenced by the existence of the Tano Tubu Office is the type of photocopy and binding services as well as the type of office stationery sales, while the determination of the type of business that is not influenced by the existence of the Tano Tubu Office is a daily necessity shop.

Table 3. Analysis of respondents' opinions about the influence of Tano Tubu Offices in determining the type of business

\begin{tabular}{|c|c|c|c|c|c|}
\hline \multirow{3}{*}{ No. } & \multirow{3}{*}{ Type of business } & \multicolumn{4}{|c|}{$\begin{array}{l}\text { The Effect of Tano Tubu Offices on the } \\
\text { determination of the type of business }\end{array}$} \\
\hline & & \multicolumn{2}{|c|}{ No Effect } & \multicolumn{2}{|c|}{ Take Effect } \\
\hline & & Amount & Percentage & Amount & Percentage \\
\hline 1. & Food and beverage stalls & 2 & $23.08 \%$ & 11 & $76.92 \%$ \\
\hline 2. & Photocopy and binding services & 0 & $.0 \%$ & 1 & $100 \%$ \\
\hline 3. & Daily necessities stalls & 1 & $100 \%$ & 0 & $.0 \%$ \\
\hline 4. & $\begin{array}{l}\text { Food and beverage stalls }+ \\
\text { Photocopy and binding services }\end{array}$ & 0 & $.0 \%$ & 2 & $100 \%$ \\
\hline 5. & $\begin{array}{l}\text { Food and beverage stalls }+ \text { Sales } \\
\text { of office stationery }\end{array}$ & 0 & $.0 \%$ & 1 & $100 \%$ \\
\hline 6. & $\begin{array}{l}\text { Food and beverage stalls + daily } \\
\text { necessities stalls }\end{array}$ & 0 & $.0 \%$ & 5 & $100 \%$ \\
\hline 7. & $\begin{array}{l}\text { Photocopy and binding services } \\
+ \text { sales of office stationery }\end{array}$ & 0 & $.0 \%$ & 4 & $100 \%$ \\
\hline 8. & $\begin{array}{l}\text { Food and beverage stalls }+ \\
\text { Photocopy and binding services } \\
+ \text { Sales of office stationery }\end{array}$ & 0 & $.0 \%$ & 2 & $100 \%$ \\
\hline 9. & $\begin{array}{l}\text { Food and beverage stalls }+ \\
\text { Office stationery sales }+ \text { Stalls } \\
\text { for daily necessities }\end{array}$ & 0 & $.0 \%$ & 1 & $100 \%$ \\
\hline \multicolumn{2}{|c|}{ TOTAL } & 3 & $10 \%$ & 27 & $90 \%$ \\
\hline
\end{tabular}

Source: Primary data, processed, 2019

From the results of the data analysis above, it is obtained that dataas much as $96.67 \%$ of business actors opened a business during the period after the establishment of the Tano Tubu office. The foregoing shows that the existence of the Tano Tubu office influences the decisions of the majority of business actors in opening a business, influences the decisions of the majority of business actors in determining the location of the business, as well as influencing the decisions of the majority of business actors in determining the type of business.

This finding strengthens previous research, namely Damanik (2014) with a thesis entitled "Study of Land Use at the City Center of Pematang Raya, the Capital of Simalungun Regency", where the results of his research are related to the findings in this study, namely the multiplier effect of the existence of regional government offices creating a central service for regional activities located in Kota Pamatang Raya and the growth of trade and service activities. The existence of the Tano Tubu office also encourages the growth of community small business actors, namely trade and services. 
The findings in this study also confirm several indicators used by Hanafiah (1982) in identifying the development of an area, namely:

1. Total population.

2. Traditional markets.

3. Number of small companies, small businesses and other stalls.

4. Perceptions of the population and their participation.

5. The level of welfare.

6. Relative number of entrepreneurs such as traders, shopkeepers and others.

7. Relative number of transportation facilities and infrastructure

According to Hanifah (1982) above, indications of the development of an area are phenomena that have occurred around the Tano Tubu office. The increase in population around the Tano Tubu office can be seen from the domicile percentage of business actors, where $73.3 \%$ of the total respondents are domiciled in the location of the business, namely around the Tano Tubu office. This increase in population is also supported by data from the analysis of the number of employees, where $36.6 \%$ of the total business actors employ employees at their place of business. Another indicator that supports the results of this study is the number of small businesses and other stalls, where the results of research in the field show that $96.67 \%$ of business actors started opening their businesses after the establishment of the Tano Tubu office.

\section{Conclusion}

There is a difference between the average income of business people around the Tano Tubu Office in the period before the Tano Tubu office and after the Tano Tubu office. The average income in the period before the establishment of the Tano Tubu Office was Rp. $2,163,382.93$, - , while the average value of income in the period after the establishment of Tano Tubu Office was Rp. 4,183,333.33. The existence of Tano Tubu Offices has a positive impact on increasing the income of the business community around it. This is indicated by the higher average income in the period after the establishment of Tano Tubu Office compared to the average income in the period before the establishment of Tano Tubu Office.

\section{References}

A [BPS] Central Bureau of Statistics, Humbang Hasundutan Regency. (2019). Humbang Hasundutan in Figures. Central Statistics Agency of Humbang Hasundutan Regency.

Budiharsono, S. (2005). Analysis Techniques for Coastal and Ocean Development. Pradya Paramita. Jakarta.

Damanik, Hotbinson. (2014). Study of Land Use in Pematang Raya City Center, the Capital of Simalungun Regency [Thesis]. Medan: University of North Sumatra, Faculty of Engineering.

[Depdikbud] Ministry of Education and Culture of the Republic of Indonesia. (1995). Big Indonesian Dictionary. Balai Pustaka. Jakarta

Hadisaroso. (1993). Basic Concept of Regional Development in Indonesia, in Prisma No. August 8, Jakarta.

Halik et al. (2020). The Effect of Administrative Implementation Principles towards the Effectiveness of Government Services. Budapest International Research and Critics Institute-Journal (BIRCI-Journal).P. 255-261

Hanafiah, T. (1982). Regional Approach and Rural Development. Faculty of Agriculture, Bogor Agricultural University. Bogor 
Hashim, Hasman. (2016). Rice Paddy Agribusiness in an Effort to Increase Farmers' Income in Regional Development in Serdang Bedagai Regency, North Sumatra Province [Desertation]. Medan: University of North Sumatra, Postgraduate School.

Kustiawan, Iwan and Anugrahani, Melani. (2000). Changes in the Use of Housing Land to Offices: Implications for Controlling Urban Spatial Use (Case Study: Cibeunying Development Area, Bandung City). Journal of Regional and City Planning ITB. Vol. 11 No. 2: 87-98.

Lase, Jhon E. (2010). Impact of the Existence of the University of North Sumatra Campus on Small Business Income and Stalls and Spatial Patterns in the Surrounding Areas [Thesis]. Medan: University of North Sumatra, Postgraduate School.

Maryatmo and Susilo. (1996). From Small Business Problems to Macro Economic Problems. Atmajaya University. Yogyakarta.

Mulyanto. HR. (2008). Principles of Regional Development. Graha Ilmu. Yogyakarta.

Nasoetion, Fact Sheet 1999. Agropolitan Approach in the Context of Regional and Rural Development. Papers of the National Seminar on Regional and Rural Development. IPB. Bogor.

Nazir, Mohammad. (1988). Research Methods. Ghalia Indonesia. Jakarta

Pane Teguh Ahmad, Sihombing Marlon, Tarmizi HB. (2013). Study on the Development of Service Centers in Serdang Bedagai Regency. Journal of Economists. Vol. 16 No. 4: 193-199.

Pradata, Y et al. (2020). Determinants of Savings and Community Loans in Ngawi District, 2010 - 2018 A Macro Economic Approach. Budapest International Research and Critics Institute-Journal (BIRCI-Journal). P. 1506-1517

Riyadi. (2002). Development of Basic Theory and Concepts in Regional Development and Regional Autonomy Concept and Development Studies. Issuer of the Center for the Study of Regional Development Technology Policy. Agency for the Assessment and Application of Technology. Jakarta.

Sirojuzilam. (2016). Regional Economic Development. USUPress. Field

Siswanto, Sunarno. (2009). Local Government Law in Indonesia. Sinar Grafiaka. Jakarta.

Shah, M et al. (2020). The Development Impact of PT. Medco E \& P Malaka on Economic Aspects in East Aceh Regency. Budapest International Research and Critics InstituteJournal (BIRCI-Journal). P. 276-286.

Soegijiko, S. (1997). A Flower of Conclusion in Indonesia's Development Planning. Grasindo. Jakarta.

Sugiyono, (2007). Educational Research Methods, Quantitative Approaches, Qualitative and R \& D. Alphabeta. Bandung.

Sugiyono.(2008). Qualitative Qualitative Research Methods and R \& D. Alfabeta. Bandung

Sukirno, Sadono. (2001). Economic Development: Processes, Problems and Policy Basis. Publishing Institute, Faculty of Economics. University of Indonesia. Jakarta.

Tarigan, R. (2005). Regional Economics: Theory and Applications. Revised Edition. Earth Literacy. Jakarta.

Todaro, MP. (2000). Economic Development in the Third World. Erlangga, Jakarta.

Warpani, Suwardjoko. (1984). City and Regional Analysis. ITB Bandung. Bandung.

Wijaya, Chandra. (2012). The Impact of the Existence of the HKBP Nommensen University Campus (UHN) Pematangsiantar on Small Business Income and Spatial Patterns in the Surrounding Areas [Thesis]. Medan: University of North Sumatra, Postgraduate School. 